\title{
Administration of Potential Medications for COVID-19 Treatment Through Feeding Tube
}

\section{COVID-19 Tedavisi için Kullanılan Potansiyel İlaçların Beslenme Tüpünden Uygulanması}

\author{
(1) Burcu KELLECi ÇAKIR*, (1) Oğuzhan FIRAT, (1) Kutay DEMIRKAN \\ Hacettepe University Faculty of Pharmacy, Department of Clinical Pharmacy, Ankara, Turkey
}

Key words: Clinical nutrition, COVID-19, clinical pharmacy, medication administration

Anahtar kelimeler: Beslenme tedavisi, COVID-19, klinik eczacılık, ilaç uygulama

\section{Dear Editor,}

The evidence behind Coronavirus disease-2019 (COVID-19) medical treatment is growing tremendously, thus, alternative administration routes of these medications should be considered especially for patients who are intubated with feeding tube (FT) or for elderly and pediatric patients with swallowing difficulties.

Administration of drugs via FT with inappropriate administration techniques can increase, decrease, or delay the effect of drugs or either clog feeding tubes. Larger diameter tubes are used in adults, thus, tube clogging is a relatively more common concern in children. ${ }^{2}$ We believe that a quick overview of this possible alternative administration for potential drugs used for COVID-19 treatment will be useful for healthcare professionals, especially in countries where alternative dosage forms are unavailable.

Various antiviral agents are used for COVID-19 treatment. Favipravir, one of those antiviral agents, can be crushed and mixed with water to be administered via FT. ${ }^{3}$ In practice, before and after each drug administration through an FT, tube should be flushed with at least $15 \mathrm{~mL}$ of water. If the oral suspension dosage form is not available, opening up the oseltamivir capsule is recommended. Since remdesivir is only available in a parenteral dosage form, it cannot be administered via FT. ${ }^{4}$

Even though hydroxychloroquine with/without azithromycin treatment is not preferred in current clinical practice, it is still recommended in some local treatment algorithms of COVID-19. Hydroxychloroquine is available in film coated tablet form. Crushing the tablets is recommended by the manufacturer to be avaoided; however; the literature recommended that tablets may be crushed if other option is unavailable. ${ }^{4}$ Azithromycin is available in tablet, capsule, and oral suspension dosage forms. Oral suspension is preferred if available. Otherwise, opening the capsules/tablets is approproate and mixing them with water for FT administration. ${ }^{4}$

When oral anticoagulants or acetylsalicylic acid are chosen for thromboprophylaxis of COVID-19, opening or crushing the dabigatran capsules is not recommended as it results in a $75 \%$ increase in their absorption. ${ }^{5}$ In addition, rivaroxaban may be crushed and suspended in $50 \mathrm{~mL}$ water prior to administration. The location distal end point of the FT should be in the stomach for better bioavailability. ${ }^{5}$ Apixaban may also be crushed and suspended with $60 \mathrm{~mL}$ water or apple juice. Crushed tablets are stable up to 4 hours in water. Edoxaban may be crushed and suspended in $60-90 \mathrm{~mL}$ of water and should be administered immediately. ${ }^{5}$

No specific usage is recommended for aspirin or other nonsteroidal antiinflammatory drugs for COVID-19 treatment in the guidelines. However, crushing the enteric-coated tablets containing acetylsalicylic acid may adversely affect the 
formulation properties, alter the bioavailability, or clog the tube, therefore administration of conventional tablets via FT should be considered. ${ }^{5}$

Corticosteroid therapy is mostly considered in patients with severe pneumonia and those who are in the intensive care unit who need oxygen support/mechanical ventilation. Treatment should be planned for short term and with low doses. Dexamethasone and methylprednisolone tablets may disperse in water quickly without the need of crushing and therefore can be administered through FT. The information on administration of prednisolone tablets through FT is not available. Therefore, parenteral application should be considered as better treatment option.

Total daily sorbitol amount over $20 \mathrm{~g}$ might cause diarrhea, therefore if liquid dosage form of any of medication is preferred, the amount of its sorbitol ingredient needs to be considered (2). Diarrhea is also one of the symptoms of COVID-19. Thus, if clinicians are unaware of sorbitol related diarrhea, this might mislead their clinical judgment.

None of these medications is confirmed for COVID-19 treatment yet, thus many countries published various treatment algorithms. Therefore, administration of these medications through FT should be the part of these possible treatment algorithms or guidelines. Furthermore, clinicians should be aware that inappropriate administration of these drugs through FT may result in treatment failure.

Conflicts of interest: No conflict of interest was declared by the authors. The authors alone are responsible for the content and writing of the paper.

\section{REFERENCES}

1. World Health Organization. (2020). Clinical management of severe acute respiratory infection (SARI) when COVID-19 disease is suspected: interim guidance. Last Accessed Date:13.03.2020 (No. WHO/2019-nCoV/ clinical/2020.4). World Health Organization. Available from: https://apps. who.int/iris/handle/10665/331446
2. Ekincioğlu A B, Demirkan K. Clinical nutrition and drug interactions. Ulus Cerrahi Derg. 2013;29:177-186.

3. Sissoko D, Laouenan C, Folkesson E, M'Lebing AB, Beavogui AH, Baize S, Camara AM, Maes P, Shepherd S, Danel C, Carazo S, Conde MN, Gala JC, Colin G, Savini H, Bore JA, Le Marcis F, Koundouno FR, Petitjean F, Lamah MC, Diederich S, Tounkara A, Poelart G, Berbain E, Dindart JM, Duraffour S, Lefevre A, Leno T, Peyrouset O, Irenge L, Bangoura N, Palich R, Hinzmann J, Kraus A, Barry TS, Berette S, Bongono A, Camara MS, Munoz VC, Doumbouya L, Harouna S, Kighoma PM, Koundouno FR, Lolamou R, Loua CM, Massala V, Moumouni K, Provost C, Samake N, Sekou C, Soumah A, Arnould I, Komano MS, Gustin L, Berutto C, Camara D, Camara FS, Colpaert J, Delamou L, Jansson L, Kourouma E, Loua M, Malme K, Manfrin E, Maomou A, Milinouno A, Ombelet S, Sidiboun AY, Verreckt I, Yombouno P, Bocquin A, Carbonnelle C, Carmoi T, Frange P, Mely S, Nguyen VK, Pannetier D, Taburet AM, Treluyer JM, Kolie J, Moh R, Gonzalez MC, Kuisma E, Liedigk B, Ngabo D, Rudolf M, Thom R, Kerber R, Gabriel M, Di Caro A, Wölfel R, Badir J, Bentahir M, Deccache Y, Dumont C, Durant JF, El Bakkouri K, Uwamahoro MG, Smits B, Toufik N, Van Cauwenberghe S, Ezzedine K, D'Ortenzio E, Pizarro L, Etienne A, Guedj J, Fizet A, de Sainte Fare EB, Murgue B, Tran-Minh T, Rapp C, Piguet P, Poncin M, Draguez B, Duverger TA, Barbe S, Baret G, Defourny I, Carroll M, Raoul H, Augier A, Eholie SP, Yazdanpanah Y, Levy-Marchal C. Antierrens A, Van Herp M, Günther S,de Lamballerie X, Keïta S, Mentre F, Anglaret X, Malvy D, JIKI Study Group. Experimental Treatment with Favipiravir for Ebola Virus Disease (the JIKI Trial): A Historically Controlled, Single-Arm Proof-of-Concept Trial in Guinea. PLoS Med. 2016;13:e1001967.

4. Experimental COVID-19 Therapies Administration in cases of swallowing difficulties, Liverpool Drug Interactions Group, 2020. Last Accessed Date: 13.03.2020. Available from: https://liverpool-covid19.s3.eu-west-2. amazonaws.com/landing-page/Covid__Swallowing_2020_Mar13.pdf

5. Lexicomp ${ }^{\circledR}$ editors take preventing medication errors as seriously as you do. Drug information. UpToDate. Last Accessed Date: 25.12.2020. Available from: https://go.wolterskluwer.com/lexicomp-drugreferences-int-b.html?utm_source=google\&utm_medium =cpc\&utm _ campaign=ALL_Lexicomp_INT_Brand\&utm_content=003-ETA-Brand_ Phrase\&utm_term=lexicomp\&gclid=CjwKCAjwkN6EBhBNEiwADVfya3c bOtcmjNAyRsKh6yKuBeGS-wkRQNvjymnYKSX2TiZX1Rcr37g8kRoCVaA QAvD_BwE 